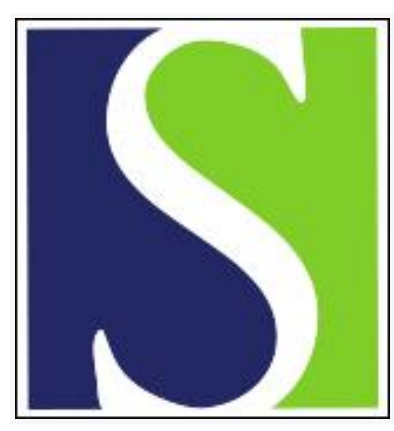

Scand J Work Environ Health 1977;3(3):154-159

https://doi.org/10.5271/sjweh.2778

Issue date: Sep 1977

Work stress in long-line bank fishing.

by Rodahl K, Vokac Z

Key terms: circulatory strain; heart rate monitoring; long-line bank fishing; long-line fishing; stress; urinary catocholomine excretion; work stress

This article in PubMed: www.ncbi.nlm.nih.gov/pubmed/910125

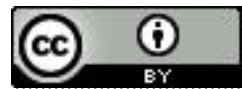




\title{
Work stress in long-line bank fishing
}

\author{
by KÅR RODAHL, M.D., and ZDENEK VOKAC, M.D. ${ }^{1}$
}

\begin{abstract}
RODAHL, K. and VOKAC, Z. Work stress in long-line bank fishing. Scand. j. work environ. \& health 3 (1977) 154-159. The circulatory strain on three Faroe Island and two Norwegian fishermen during long-line bank fishing was assessed by the computerized analysis of their heart rates continuously recorded by portable tape recorders. The urinary excretion of catecholamines was assayed as an indicator of stress response. The average work load of the three Faroe Island deckhands was rather moderate; it corresponded to $26-33 \%$ of the heart rate reserve (HRR). However, heart rates higher than $50 \%$ of the HRR $(9-18 \mathrm{~min} / 24 \mathrm{~h})$ as well as peak heart rates up to 165 beats $/ \mathrm{min}$ indicated periods of intense physical strain, especially when the fish were being unhooked, an operation which, as a rule, cannot be endured for more than about $25 \mathrm{~min}$ at a time and which necessitates a work schedule of job rotation. These observations were confirmed by the findings made on board the Norwegian vessel. The urinary catecholamine excretion rates were lower than those of coastal fishermen and of the same order of magnitude as the excretion rates observed in trawler fishermen. It is concluded that, contrary to general belief, bank fishing need not be unsuitable for older fishermen, provided an effective system of job rotation is practiced and the size of the crew is large enough to allow for an adequate amount of sleep even during periods of exceptionally good fishing.
\end{abstract}

Key words: circulatory strain, heart rate monitoring, long-line fishing, urinary catecholamine excretion.

Pelagic fishing, especially long-line fishing for dogfish on the North Atlantic fishing banks, is usually considered an arduous occupation, unsuitable for persons over the age of 50. The purpose of this study was to assess the magnitude of the physical work stress encountered in longline bank fishing in comparison to the level previously reported for coastal fishing (4).

The wholesale value of the Norwegian bank fishing was roughly estimated to be about 150 million Norwegian crowns in 1976 (Norwegian Directorate of Fisheries, unpublished statistics), or less than $10 \%$ of the gross value of the Norwegian catch

1 Institute of Work Physiology, Oslo, Norway. Reprint requests to: Prof. K. Rodahl, Institute of Work Physiology, Gydas vei 8, Oslo 3, Norway. as a whole. In 1976 a total of 149 Norwegian vessels took part in bank fishing, but only 68 of them were engaged in it for more than 30 weeks of the year ( 38 weeks on the average). The average size of these 68 vessels, engaged in what may be called year-round bank fishing, was $25.6 \mathrm{~m}$ and 127 GRT. $^{2}$ The mean age of these vessels was 17 years. The size of the crew of the bank fishing vessels varied from district to district. In Finnmark in the north of Norway where the distance to the fishing banks is short, the vessels are small, the trip lasts only a few days, and the crew may total only 5-6 men on the average. Vessels operating from the west coast of Norway usually have a crew of 7-11 men and the duration of each trip

2 GRT: gross registered tonnage. 
may vary from $4-5$ days up to 4 weeks. In addition to this fleet of bank fishing vessels, there were, in 1976, eight larger Norwegian vessels engaged in long-line fishing west of Greenland and east of Labrador and Newfoundland with crews of 12-15 men on the average.

\section{MATERIAL AND METHODS}

The study was made on board two longline fishing vessels. The first ship (F) was a modern vessel ( $36.6 \mathrm{~m}$ long, 242 GRT) from the Faroe Islands with a crew of 15 fishing for Greenland halibut off the coast of Labrador. A team of six men took care of the fishing proper, i.e., baiting hooks, unhooking fish, operating the winch, etc. A second team of six processed the catch and stored the fish on ice in deep-freeze rooms. The arrangement of the work schedules of both teams was flexible and no strict watches were followed. The crew acted more or less like a large family sharing the work as required according to the size of the catch. The two teams changed jobs every week.

Before leaving for the fishing banks three deckhands (subjects $1-3$ ) belonging to the same team were examined in the field laboratory on shore. The steady-state heart rate responses to known work loads $(50,100,150 \mathrm{~W})$ engaging large muscle groups, as well as the maximal aerobic power of each subject, were assessed on a mechanically braked bicycle ergometer (Monark, Varberg, Sweden).

Upon arrival at the fishing banks detailed records of the type, sequence, and duration of the activities of the subjects were kept for $72 \mathrm{~h}$. The circulatory strain of the subjects during the observation period was assessed from the heart rate continuously recorded by portable tape recorders (Hellige, Freiburg/Breisgau, Germany). The recorded heart rates were quantitatively evaluated with the aid of a digital computer.

The linear relationship between submaximal work rates and the heart rates assessed in the laboratory made it possible to express the heart rates recorded on board in comparable terms of the percentage of the individual's heart rate reserve.
Heart rate reserve (HRR) is defined as the difference between resting and maximal heart rate. The lowest heart rate recorded during the long rest pauses when awake was regarded as the subject's actual resting rate, while the maximal heart rates were obtained in the laboratory. The details of the procedures and methods used both in the laboratory and on the ships were essentially the same as those used in our previous investigation of coastal fishing (4). In addition, as a general indication of the stress involved, the urinary excretion rates of epinephrine and norepinephrine were assessed (5) from urine collected between 0800 and 2000 and between 2000 and 0800 . The weather was fair during the whole 72 -h observation period and the size of the catch was considered average.

The second ship (N) was a Norwegian vessel (32.9 $\mathrm{m}$ long, $190 \mathrm{GRT}$ ) with a crew of 11 fishing for dogfish off the Orkney Islands. The arrangement of the work schedule of the seven deckhands called for continuous job rotation so that each man changed stations in a regular pattern: letting out the long line, unhooking the catch, operating the winch, bleeding the fish, storing the fish, and baiting the hooks. When the fishing was exceptionally good, the whole crew had to work without sufficient sleep, at times for several consecutive days. The weather was very unfavorable with winds up to gale force and a heavy sea during the whole trip. The catch was average.

Two deckhands (subjects $\mathrm{A}$ and $\mathrm{B}, 22$ and 49 years old, respectively) served as subjects during a 5-day observation period. Their heart rate was monitored in the aforementioned manner. For technical reasons it was not possible for the subjects to perform submaximal work tests or for us to measure their maximal aerobic power.

\section{RESULTS}

From table 1 it can be seen that the physical work capacity of the three crew members from vessel $F$ was fair to good (1) and comparable to that of coastal fishermen. The recorded maximal heart 
Table 1. Physical characteristics of the subjects followed on ship $F$ and the results of their maximal effort tests.

\begin{tabular}{|c|c|c|c|c|c|c|c|}
\hline \multirow[b]{2}{*}{ Subject } & \multirow{2}{*}{$\begin{array}{c}\text { Age } \\
\text { (years) }\end{array}$} & \multirow{2}{*}{$\begin{array}{l}\text { Height } \\
\text { (cm) }\end{array}$} & \multirow{2}{*}{$\begin{array}{l}\text { Weight } \\
\text { (kg) }\end{array}$} & \multicolumn{2}{|c|}{ Oxygen uptake } & \multirow{2}{*}{$\begin{array}{l}\text { Heart rate } \\
\text { (beats } / \mathrm{min} \text { ) }\end{array}$} & \multirow{2}{*}{$\begin{array}{c}\text { Lactic } \\
\text { acid } \\
(\mathrm{mM} / 1)\end{array}$} \\
\hline & & & & $\begin{array}{l}1 / \min \\
\mathrm{STPD}\end{array}$ & $\begin{array}{c}\mathrm{ml} / \mathrm{kg} \cdot \min \\
\mathrm{STPD}\end{array}$ & & \\
\hline 1 & 28 & 176 & 82 & 3.3 & 40 & 190 & 8.9 \\
\hline 2 & 20 & 178 & 72 & 2.9 & 40 & 205 & 8.4 \\
\hline 3 & 20 & 175 & 65 & 3.0 & 46 & 196 & 12.0 \\
\hline
\end{tabular}

rates and measured peak blood lactate levels indicate that the ergometer test closely represented the maximal effort of the subjects.

The sequence and duration of the spacific activities of the three deckhands on board ship $F$ during the entire 72-h observation period is presented graphically in the lower part of fig. 1 . The rather irregular pattern of work, rest and sleep is due to the flexible work schedule practiced on board this ship. A moredetailed comparison of the work activities of the three subjects, as baiting hooks, unhooking fish, etc., shows that they participated in all types of work and rotated from one task to another as the situation required. It is evident from table 2 that in the long run $(72 \mathrm{~h})$ the average work load of the three subjects was practically the same in spite of the irregular activity patterns. They spent about onethird of the time actually working, onethird resting and one-third sleeping, similar to the pattern observed among trawler fishermen working in strict $6-\mathrm{h}$ watches (3).

The average work load of the three deckhands over a 24-h period, as judged by their mean circulatory strain, was rather moderate $(25-33 \%$ of the HRR). However, the average 9- to 18-min duration of the heart rate higher than $50 \%$ of the HRR, as well as the peak heart

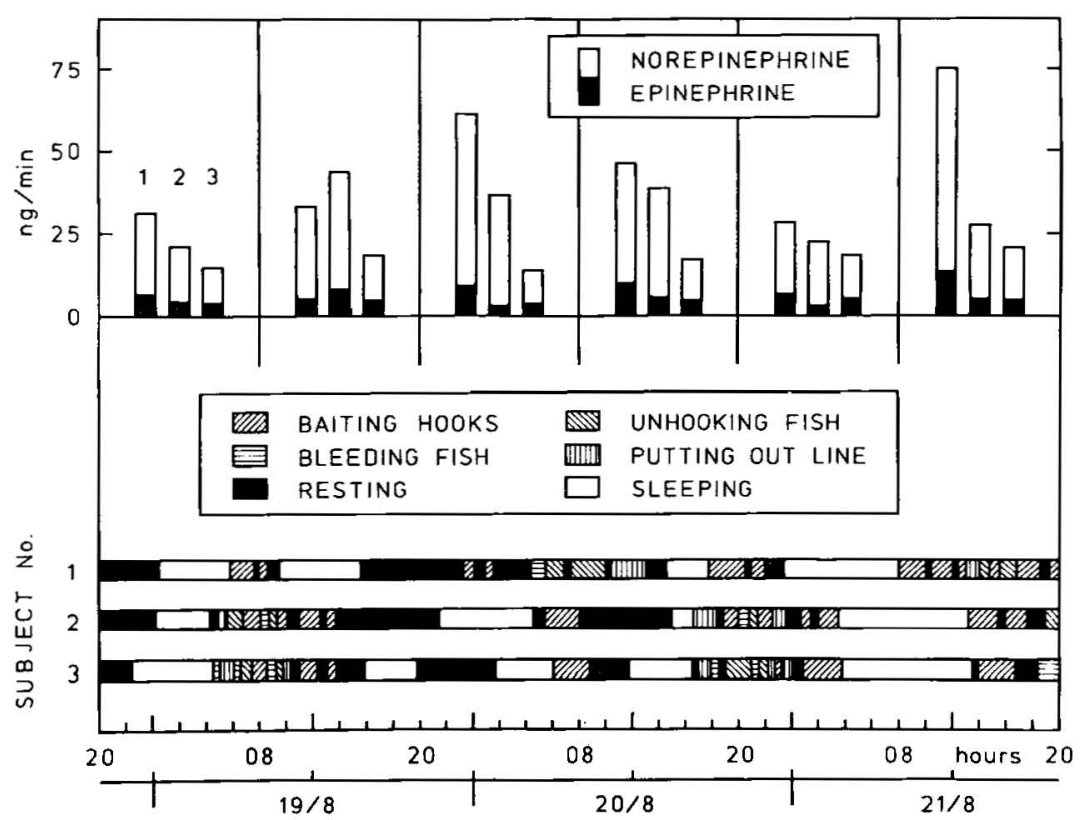

Fig. 1. Lower part: Activity patterns of three deckhands from ship F during the 72-h observation period. Upper part: Mean urinary excretion rates of epinephrine and norepinephrine in 12-h periods. 
Table 2. Heart rate $(\mathrm{HR})$ and the percentage of heart rate reserve (HRR a) in basic categories of the $24-h$ schedule on board ship $F$.

\begin{tabular}{|c|c|c|c|c|c|c|c|c|}
\hline \multirow[t]{2}{*}{ Subject } & \multirow[t]{2}{*}{ Category } & \multirow{2}{*}{$\begin{array}{l}\text { Duration } \\
\text { (min) }\end{array}$} & \multirow{2}{*}{$\begin{array}{c}\text { Percentage } \\
\text { of 24-h } \\
\text { schedule }\end{array}$} & \multicolumn{2}{|c|}{$\begin{array}{l}\text { Heart rate } \\
\text { (beats } / \mathrm{min} \text { ) }\end{array}$} & \multicolumn{2}{|c|}{$\begin{array}{c}\text { Percentage } \\
\text { of HRR }\end{array}$} & \multirow{2}{*}{$\begin{array}{c}\text { Duration } \\
\text { of } \mathrm{HR}> \\
50 \% \text { HRR } \\
\text { (min) }\end{array}$} \\
\hline & & & & Mean & Range & Mean & Range & \\
\hline 1 & $\begin{array}{l}\text { Work } \\
\text { Rest b } \\
\text { Sleep }\end{array}$ & $\begin{array}{l}514 \\
473 \\
453\end{array}$ & $\begin{array}{l}36 \\
33 \\
31\end{array}$ & $\begin{array}{r}106 \\
90 \\
68\end{array}$ & $\begin{array}{l}80-145 \\
65-115 \\
60-90\end{array}$ & $\begin{array}{l}33 \\
20\end{array}$ & $\begin{array}{r}12-64 \\
0-40\end{array}$ & 18 \\
\hline 2 & $\begin{array}{l}\text { Work } \\
\text { Rest b } \\
\text { Sleep }\end{array}$ & $\begin{array}{l}477 \\
527 \\
436\end{array}$ & $\begin{array}{l}33 \\
37 \\
30\end{array}$ & $\begin{array}{l}99 \\
82 \\
63\end{array}$ & $\begin{array}{l}75-165 \\
65-115 \\
55-90\end{array}$ & $\begin{array}{l}25 \\
12\end{array}$ & $\begin{array}{l}8-72 \\
0-36\end{array}$ & 17 \\
\hline 3 & $\begin{array}{l}\text { Work } \\
\text { Rest b } \\
\text { Sleep }\end{array}$ & $\begin{array}{l}484 \\
394 \\
562\end{array}$ & $\begin{array}{l}34 \\
27 \\
39\end{array}$ & $\begin{array}{l}98 \\
83 \\
59\end{array}$ & $\begin{array}{l}80-160 \\
65-120 \\
55-90\end{array}$ & $\begin{array}{l}26 \\
14\end{array}$ & $\begin{array}{r}12-73 \\
0-43\end{array}$ & 9 \\
\hline
\end{tabular}

a Difference between resting and maximal heart rate.

b Rest pauses when on duty and awake during free watches.

rates up to 165 beats/min, indicate periods of intense physical strain, especially when the fish were being unhooked. On the whole, similar, though slightly higher, work loads were observed in deckhands on board trawlers (3) and a still higher strain was found in the long-line fishermen engaged in coastal fishing (4).

The urinary catecholamine excretion rates in the three subjects studied on board ship $F$ are shown in the upper part of fig. 1. They are of the same order of magnitude as the excretion rates observed for trawler fishermen whose work load was about the same as our subjects' (3). The results indicate persistent interindividual differences in catecholamine elimination rates (2).

In general, these observations were confirmed by the findings made on board ship N. Here, due to rough weather and technical difficulties, the monitoring of the heart rate was not continuous for the whole duration of the trip. Nevertheless, the recorded heart rate curves illustrate well some of the points raised previously. Fig. 2 shows an example of the circulatory strain when the catch was being stored on

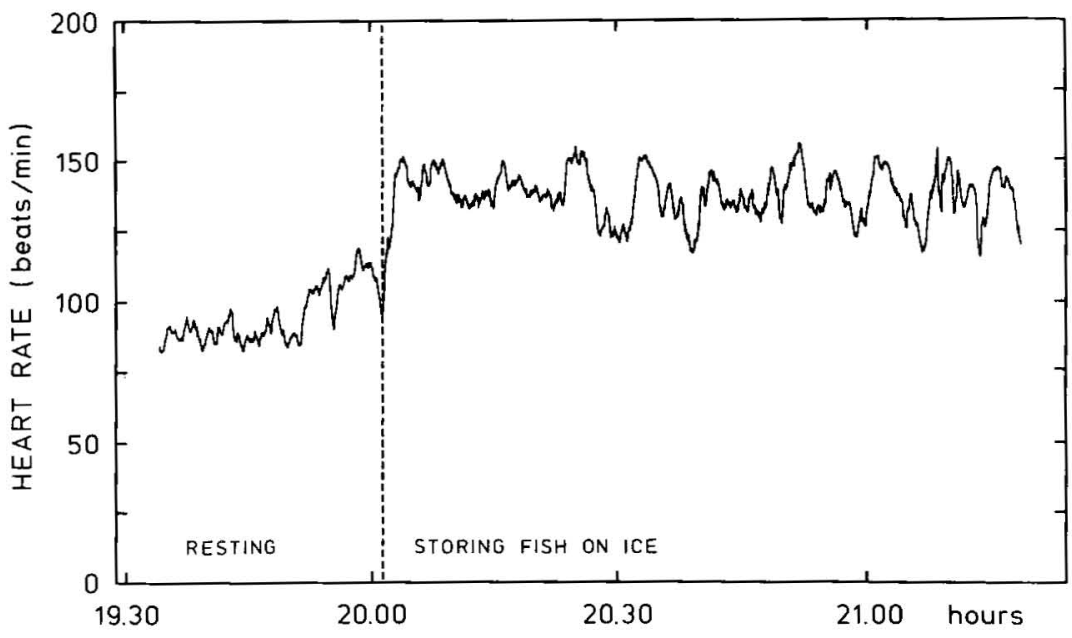

Fig. 2. Heart rate of one deckhand from ship $\mathrm{N}$ when he was storing fish on ice (subject $\mathrm{A}$ in fig. 3). The intermittent character of the strenuous work is reflected by the periodical changes $(3-4 \mathrm{~min})$ in the heart rate. 


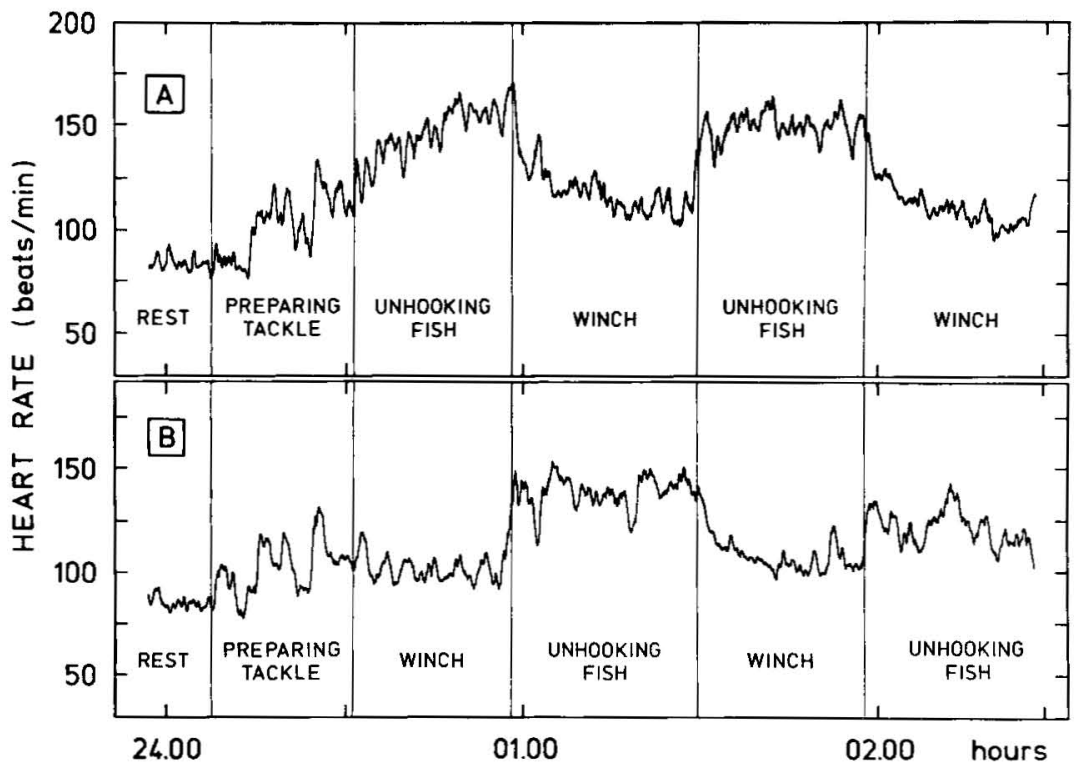

Fig. 3. Simultaneous recordings of the heart rates of two deckhands from ship $\mathrm{N}$ who alternated regularly between unhooking fish and operating the winch.

ice, a rather strenuous operation involving heart rates around 150 beats/min for over an hour. However, the work has a rhythmical, intermittent character with 3to 4-min periods of intense effort followed by about the same duration of less intense activity.

By far the most strenuous operation in any long-line fishing boat is the unhooking of the fish as the line is pulled in by winch over the side of the ship. It is generally considered that, at times when the fishing is good and there is a dogfish on about every hook, this particular operation cannot be endured for more than about $25 \mathrm{~min}$ at a stretch. Consequently, a routine is established whereby the deckhand unhooking the fish and another deckhand operating the winch change places at regular intervals. The high degree of circulatory strain during the unhooking process and the following recovery when the winch is operated is evident from fig. 3 . Such simultaneous recordings were made for two subjects during 11 periods of unhooking fish and operating the winch. The mean heart rates were 154 (range 115-190) for subject $A$ and 134 (105-155) for subject B when unhooking fish. The corresponding mean heart rates when the winch was being operated were $130(105-160)$ for $A$ and $113(95-140)$ for $B$.

The catecholamine excretion rates of the two deckhands were similar to those assessed on board ship F. The epinephrine elimination varied from 4 to $28 \mathrm{ng} / \mathrm{min}$ and the norepinephrine values ranged from 16 to $62 \mathrm{ng} / \mathrm{min}$.

\section{DISCUSSION}

This study shows that under normal circumstances (ship $F$ ) the physical load involved in long-line fishing on fishing banks in distant waters is not especially high. However, it may increase considerably when the fishing is particularly good (ship N). If, occasionally, such abundant fishing lasts for a long period of time, another additional factor enhances the strain severely. Especially with reduced crews it is necessary in such cases that the entire crew work practically around the clock for several days, and the resulting lack of sleep may be considerable.

An interesting finding of the study is the fact that even though the work routine is very flexible (ship F, fig. 1), the crew 
members tend to attain a schedule which, on the average, divides equally the duration of work, rest and sleep periods as in the case on board the ships where 6-h watches are strictly adhered to (3).

A further interesting observation is the fact that, as a matter of necessity, the crew has resorted of their own accord to a system of job rotation, alternating between heavy and light work operations in order to provide necessary recuperation between periods of strenuous exertion (fig. 3).

As mentioned in the introduction, bank fishing has generally been considered an arduous occupation unsuitable for persons over the age of 50 . The results of the present study suggest that this need not be the case provided an effective system of job rotation is practiced on board ship and provided the size of the crew is sufficiently large to allow for an adequate amount of sleep even during periods of exceptionally good fishing.

\section{ACKNOWLEDGMENTS}

The authors are indebted to the Norwegian Directorate of Fisheries, Office for Econo- mic Studies and Statistics, for valuable assistance in obtaining statistical information pertaining to Norwegian bank fishing. Thanks are due to Mr. P. O. Huser, Mr. E. Krogstad, Ms. I. Liaaen, Dr. S. Maehlum and Mr. A. Rodahl for their technical assistance.

\section{REFERENCES}

1. ÅSTRAND, I. Aerobic work capacity in men and women with special reference to age. Acta physiol. scand. 49 (1960): suppl. 169

2. JOHANSSON, G. and POST, B. Catecholamine output of males and females over a one-year period. Acta physiol. scand. 92 (1974) $557-565$.

3. RODAHL, $\mathrm{K}$. and VOKAC, Z. Work stress in Norwegian trawler fishermen. Ergonomics (in press).

4. RODAHL, K., VOKAC, Z., FUGELLI, P., VAAGE, O. and MAEHLUM, S. Circulatory strain, estimated energy output and catecholamine excretion in Norwegian coastal fishermen. Ergonomics 17 (1974) $585-602$.

5. VAAGE, O. Fluorometric determination of epinephrine and norepinephrine in $1 \mathrm{ml}$ urine introducing dithiothreitol and boric acid as stability- and sensitivity-improving agents of the trihydroxyindole method. Biochem. med. 9 (1974) 41-53. 